\section{Single-step Elimination of Contaminating DNA Prior to Reverse Transcriptase PCR}

\author{
Donald D. Dilworth \\ and John R. McCarrey
}

Department of Genetics, Southwest Foundation for Biomedical Research, San Antonio, Texas 78228
The reverse transcriptase-polymerase chain reaction (RT-PCR) provides an effective method for detecting very small amounts of a specific mRNA in a small sample of total RNA. ${ }^{(1,2)}$ Unfortunately, for purposes of detecting RNA by this procedure, after the initial step of converting RNA into cDNA using reverse transcriptase, the multiple rounds of amplification catalyzed by DNA polymerase are equally effective at amplifying either the cDNA or contaminating genomic DNA. Even minuscule amounts of contaminating DNA $(<1 \%)$ can produce a falsepositive amplification signal in an RT.

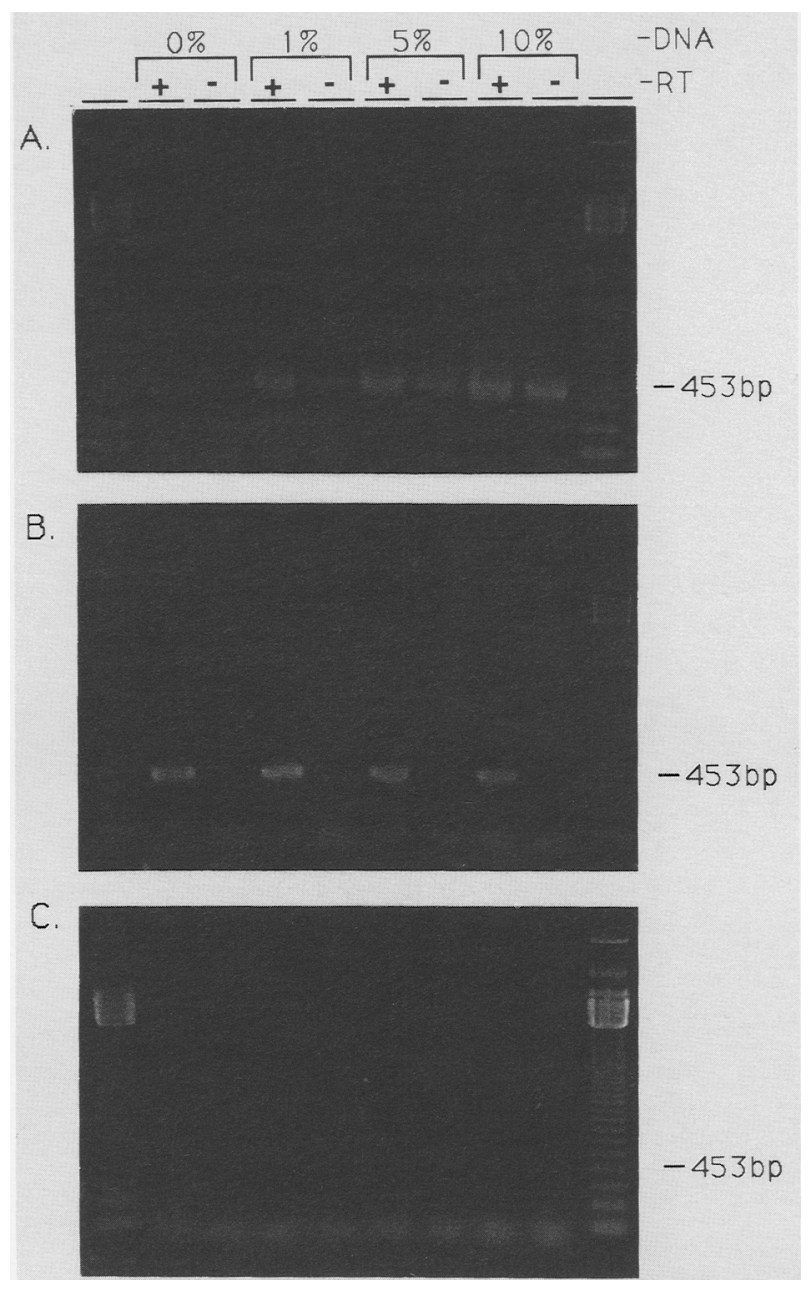

FICURE 1 Effects of pretreatment with nuclease on production of amplification signals by RT-PCR. Five hundred nanograms of total RNA from mouse liver supplemented with $0,1,5$, or $10 \%$ genomic DNA was subjected to RT-PCR using primers determined from the mouse $\beta$ actin cDNA sequence, ${ }^{(14)}$ and reverse transcriptase and AmpliTaq DNA polymerase (PerkinElmer Cetus). Primers used were: (upstream) $5^{\prime}$-GCGGACTGTTACTGAGCTGCGT-3' and (downstream) 5'-GAAGCAATGCTGTCACCTTCCC-3', which delineated a 453-bp amplification product from either a cDNA or genomic DNA template, since this sequence apparently does not span an intron in genomic DNA. In each case a comparison of amplification with $(+)$ or without $(-)$ the addition of reverse transcriptase is shown. $(A)$ RT-PCR with no prior nuclease treatment. Note amplification signal in both $+\mathrm{RT}$ and $-\mathrm{RT}$ lanes, with increasing intensity in -RT lane coincident with increasing levels of contaminating DNA. The faint signal in the $0 \% \mathrm{DNA} /-\mathrm{RT}$ lane indicates endogenous DNA contamination in the RNA preparation, which represents $<1 \%$ of the total nucleic acid. (B) RT-PCR following treament with DNase I. Note persistent signal in $+\mathrm{RT}$ lanes, but absence of signal in -RT lanes. (C) RT-PCR following treatment with both DNase $I$ and RNases $A$ and $T 1$. Note the absence of amplification signal in both the +RT and - RT lanes. Restriction endonuclease cleavage of the amplification product with Rsal was used to confirm amplification of the $\beta$-actin template in each case (data not shown). A 123-bp DNA ladder (BRL) was run in each of the outside lanes to confirm molecular size of the amplification product. 
PCR reaction (Fig. 1). One method to distinguish amplification signals templated by genomic DNA versus mRNAderived CDNA is to use primers that span an exon-exon junction in the cDNA, such that the presence of an intron in the genomic DNA template will yield a larger amplification product than that emanating from the intronless cDNA template. (3) However the necessary sequence information to design such primers (i.e., location of introns) is not always known for a particular gene, and some functional genes lack introns, as do all processed pseudogenes. Thus, it is often desirable to be able to eliminate contaminating genomic DNA directly from samples of RNA prior to RT-PCR.

DNA can be eliminated from RNA samples by treatment with RNase-free DNase I as a separate step in the purification of total RNA. ${ }^{(4-6)}$ However RT-PCR is often used to analyze very small samples of total RNA, and attempts to recover such small amounts of RNA following a separate DNase digestion step can result in the loss of all nucleic acid, including RNA. Recovery can be augmented by addition of carrier RNA, but this introduces another potential source of amplification artifact. We have developed a one-step procedure for the removal of contaminating genomic DNA from RNA samples that can be carried out in the same tube as the subsequent RT-PCR reaction, without addition of carrier RNA. We show here that this procedure can effectively remove even very large amounts of contaminating genomic DNA, with no appreciable loss of RNA.

\section{METHODS}

RT-PCR was performed using the GeneAmp RNA PCR kit (Perkin-Elmer Cetus) according to manufacturer's instructions, modified to facilitate treatment of the sample with DNase I. The DNase I treatment was carried out in the same reaction mix as the reverse transcriptase step, prior to addition of reverse transcriptase. Five hundred nanograms of total RNA isolated from mouse liver as described ${ }^{(7)}$ in $2 \mu \mathrm{l}$ of diethyl pyrocarbonate (DEPC)-treated water was mixed with $16.6 \mu \mathrm{l}$ of reverse transcriptase master mix excluding reverse transcriptase [final concentra- tions in $20 \mu \mathrm{l}=5 \mathrm{mM} \mathrm{MgCl}_{2}, 1 \times \mathrm{PCR}$ buffer $(50 \mathrm{~mm} \mathrm{KCl}, 10 \mathrm{~mm}$ Tris- $\mathrm{HCl}, \mathrm{pH}$ 8.3), $1 \mathrm{~mm}$ each dNTPs, 20 units of RNase inhibitor, $2.5 \mu \mathrm{M}$ random hexamers (note: the DNase treatment did not seem to affect these short, singlestranded primers)]. Contaminating DNA was removed by adding $0.4 \mu \mathrm{l}$ of $0.25 \mu \mathrm{g} / \mu \mathrm{l}$ RNase-free DNase I (U.S. Biochemical, and incubating at $37^{\circ} \mathrm{C}$ for $30 \mathrm{~min}$. To test the potential extent of elimination of genomic DNA by this method, some RNA samples were spiked with varying amounts of genomic DNA isolated from mouse liver as described. ${ }^{(4)}$ The reaction was stopped by heating to $95^{\circ} \mathrm{C}$ for $5 \mathrm{~min}$, then cooled to room temperature. One microliter of $50 \mathrm{U} / \mu \mathrm{l}$ reverse transcriptase was then added and the RT-PCR procedure followed according to manufacturer's instructions, including one round of reverse transcription $\left(42^{\circ} \mathrm{C}\right.$, $15 \mathrm{~min} ; 99^{\circ} \mathrm{C}, 5 \mathrm{~min} ; 5^{\circ} \mathrm{C}, 5 \mathrm{~min}$ ) in a total volume of $20 \mu \mathrm{l}$, followed by addition of $80 \mu$ l of PCR master mix containing Taq polymerase and primers specific for mouse cytoskeletal $\beta$-actin (final concentrations in $100 \mu \mathrm{l}=2 \mathrm{mM}$ $\mathrm{MgCl}_{2}$, 1x PCR buffer, 2.5 units of AmpliTaq DNA polymerase, and 125 $\mathrm{ng}$ each of upstream and downstream specific primers), and 35 cycles of PCR (each cycle $=94^{\circ} \mathrm{C}, 1 \mathrm{~min} ; 54^{\circ} \mathrm{C}, 1$ $\min ; 72^{\circ} \mathrm{C}, 1 \mathrm{~min}$, with a $5 \mathrm{sec} /$ cycle extension of the $72^{\circ} \mathrm{C}$ step). Fifteen microliters of reaction product was then electrophoresed through $1.5 \%$ agarose and visualized by staining with ethidium bromide. "No-RT" controls were run as above except that water was substituted for reverse transcriptase. Treatment of some samples with both RNase and DNase was performed as an additional control by adding $0.1 \mu \mathrm{g}$ RNase $A$ and 5 units of RNase T1 (GIBCO-BRL) to the DNase step and reducing the water to keep the total volume at $19 \mu \mathrm{l}$.

\section{RESULTS AND DISCUSSION}

The presence or absence of an RT-PCR amplification signal emanating from contaminating genomic DNA can be detected by running a "no-RT" (no reverse transcriptase added) control. Figure 1A shows the presence of contaminating DNA in samples of total RNA that were not treated with DNase I, as indicated by positive signals in the
no-RT (-RT) lanes. Note that contaminating DNA present at levels of less than $1 \%$ is sufficient to produce a noticable amplification signal. Figure 1 B shows that treatment with DNase I effectively eliminates the DNA signal (no band in -RT lanes), but leaves the RNA signal intact (signal in $+\mathrm{RT}$ lanes). That the signals in the $+R T$ lanes in Figure $1 \mathrm{~B}$ were indeed produced by RNA templates was confirmed by treating with DNase plus RNase, which eliminated the signals from both the + RT and -RT lanes, as shown in Figure 1C. These results demonstrate that the DNase I treatment we describe can eliminate up to $10 \%$ of contaminating DNA from a 500-ng sample of total RNA, which represents a much higher level of contamination than normally observed. In fact, we found that this treatment can eliminate up to $100 \%$ DNA (500 ng) (data not shown), indicating that it is sufficient to remove any amount of contaminating DNA from a standard 500-ng RNA sample.

The absence of a signal in any of the no-RT lanes in Figure 1B indicates that under these conditions the AmpliTaq DNA polymerase used does not show RT activity. We also tested the native Taq polymerase for RT activity under our RT-PCR conditions, and again observed no signal in the -RT lanes (Fig. 2). Finally we tested both AmpliTaq and native Taq, along with two other thermostable DNA polymerases, Vent (New England Biolabs) and Pfu (Stratagene), for apparent RT activity under standard DNA PCR conditions by testing each on DNA versus RNA templates (Fig. 3). We observed no evidence for any RT activity in the AmpliTaq, native Taq, or Pfu polymerases under the conditions described. The Vent polymerase did produce a faint amplification product from DNase I-treated RNA, suggesting the possibility of very minor RT activity associated with this enzyme under these conditions.

The occurrence of RT activity in one thermostable DNA polymerase, the Thermus thermophilus (rTth) DNA polymerase (Perkin-Elmer Cetus), in the presence of manganese ion is well documented $^{(8)}$ and undisputed. However, reports of RT activity associated with the $T a q$ polymerases are more variable. Myers and Gelfand ${ }^{(8)}$ reported 


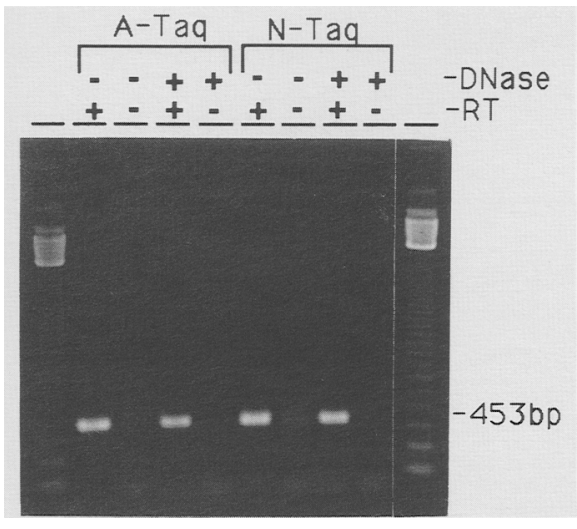

FICURE 2 Analysis of AmpliTaq and native Taq polymerases for reverse transcriptase activity during RT-PCR. Five hundred nanograms of RNA plus $1 \%$ genomic DNA was subjected to RT-PCR to detect mouse $\beta$ actin mRNA with either AmpliTaq polymerase (A-Taq) or native Taq polymerase (N-Taq) (Perkin-Elmer Cetus), following pretreatment with DNase I $(+)$ or without DNase I $(-)$, and with RT $(+)$ or without RT (-). Note the presence of amplification signals in all $+\mathrm{RT}$ lanes, and in -RT lanes containing samples not pretreated with DNase I, but not in -RT lanes containing DNase-treated samples. A 123-bp ladder was run in each outside lane as a marker.

that the AmpliTaq polymerase failed to show RT activity in the presence of manganese ion, suggesting it lacks the RT activity associated with the rTth polymerase. Other reports of significant RT activity of Taq polymerases in the presence of magnesium ion ${ }^{(9-11)}$ stand in contrast to the results reported here as well as numerous reports of negative results from no-RT controls in RT-PCR experiments (e.g., refs. 3 and 12). The source of these discrepancies is not clear, although the abundance of potential sources of artifactual positive results in PCR reactions is well documented. ${ }^{(13)}$

We conclude that pretreatment of RNA samples with DNase I, followed by standard RT-PCR in the same tube, as described here, results in elimination of contaminating DNA and facilitates an accurate assessment of RNAtemplated PCR. We further conclude that under the conditions we describe here, none of the DNA polymerases we tested show significant RT activity, suggesting that a no-RT reaction provides an informative control against artifactual amplification signals pro-

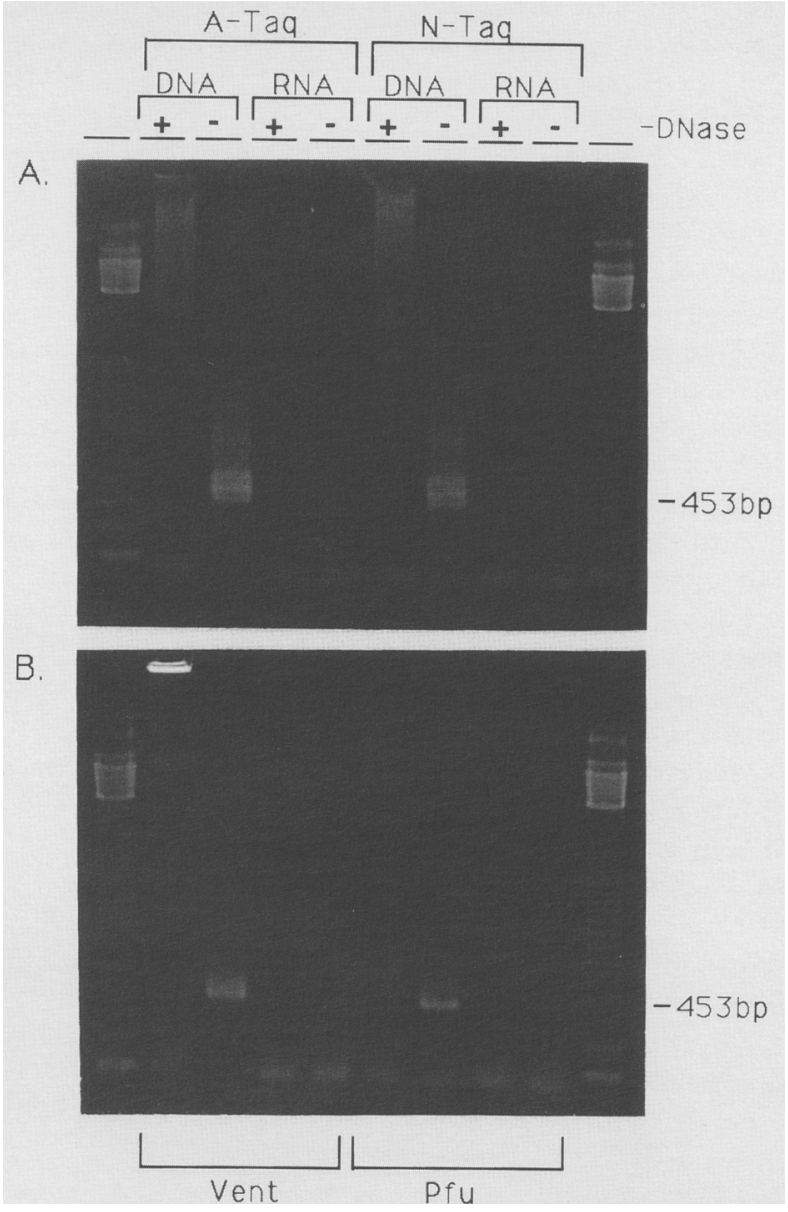

FICURE 3 Analysis of AmpliTaq, native Taq, Vent, and Pfu polymerases for reverse transcriptase activity during PCR. Five hundred nanograms of genomic DNA or $500 \mathrm{ng}$ of total RNA from mouse liver were subjected to DNA PCR following pretreatment with DNase I (+) or without DNase I (-). DNase pretreatment was performed as described in the text, followed by 35 cycles of DNA PCR. Four different DNA polymerases were tested, including AmpliTaq (ATaq) (Perkin-Elmer Cetus), native Taq (N-Taq) (Perkin-Elmer Cetus), Vent (New England Biolabs), and Pfu (Stratagene), each with its own buffer supplied by the manufacturer. In each case, pretreatment of the DNA sample with DNase I eliminated the amplification signal that was otherwise obtained without DNase I pretreatment (453-bp band). Both the AmpliTaq and Vent polymerases amplified a weak signal from the untreated RNA templates. Neither the AmpliTaq, native Taq, nor Pfu polymerases amplified any signal from the DNase I-treated RNA samples, however the Vent polymerase did produce a very weak signal from DNase I-treated RNA. A 123-bp ladder was run in each outside lane as a marker.

duced from contaminating genomic DNA templates.

\section{ACKNOWLEDGMENT}

This work was supported by a grant from the National Science Foundation to J.R.M. (DMB-9196091). The authors thank Dr. John Rossi for reading the manuscript.

\section{REFERENCES}

1. Rappolee, D.A., D. Mark, M.J. Banda, and Z. Werb. 1988. Wound macro- phages express TGF- $\alpha$ and other growth factors in vivo: Analysis by mRNA phenotyping. Science 241: 708-712.

2. Murakawa, G.J., J.A. Zaia, P.A. Spallone, D.A. Stephens, B.E. Kaplan, R.B. Wallace, and J.J. Rossi. 1988. Direct detection of HIV-1 RNA from AIDS and ARC patient samples. DNA 7: 287-295.

3. Mivechi, N.F. and J.J. Rossi. 1990. Use of polymerase chain reaction to detect the expression of the $M_{\mathrm{r}}$ 


\section{Technical TipsIIIII $\square$}

70,000 heat shock genes in control or heat shock leukemic cells as correlated to their heat response. Cancer Res. 50: 2877-2884.

4. Sambrook, J., E.F. Fritsch, and T. Maniatis. 1989. Molecular cloning: $A$ laboratory manual, 2nd ed. Cold Spring Harbor Laboratory Press, Cold Spring Harbor, New York.

5. Byrne, B.C., J.J. Li, J. Sninsky, and B.J. Poiesz. 1988. Detection of HIV-1 RNA sequences by in vitro DNA amplification. Nucleic Acids Res. 16: 4165.

6. Al-Sumidaie, A.M., S.J. Leinster, C.A. Hart, C.D. Green, and K. McCarthy. 1988. Particles with properties of retroviruses in monocytes from patients with breast cancer. Lancet i: 5-9.

7. Chirgwin J.M., A.E. Przybyla, R.J. MacDonald, and W.J. Rutter. 1979. Isolation of biologically active ribonucleic acid from sources enriched in ribonuclease. Biochemistry 18: 52945299.

8. Myers, T.W. and D.H. Gelfand. 1991. Reverse transcription and DNA amplification by a Thermus thermophilus DNA polymerase. Biochemistry 30: 7661-7666.

9. Tse, W.T. and B.G. Forget. 1990. Reverse transcription and direct amplification of cellular RNA transcripts by Taq polymerase. Gene 88: 293-296.

10. Jones, M.D. and N.S. Foulkes. 1989. Reverse transcription of mRNA by Thermus aquaticus DNA polymerase. Nucleic Acids Res. 17: 8387-8388.

11. Shaffer, A.L., W. Wojnar, and W. Nelson. 1990. Amplification, detection, and automated sequencing of gibbon interleukin-2 mRNA by Thermus aquaticus DNA polymerase reverse transcription and polymerase chain reaction. Anal. Biochem. 190: 292-296.

12. Zhang, L.Q., P. Simmonds, C.A. Ludlam, and A.J.L. Brown. 1991. Detection, quantification and sequencing of HIV-1 from the plasma of seropositive individuals and from factor VIII concentrates. AIDS 5: 675-681.

13. Kwok, S. and R. Higuchi. 1989. Avoiding false positives with PCR. Nature 339: 237-238.

14. Tokunaga, K., H. Taniguchi, K. Yoda, M. Shimizu, and S. Sakiyama. 1986. Nucleotide sequence of a full-length
CDNA for mouse cytoskeletal $\beta$-actin mRNA. Nucleic Acids Res. 14: 2829.

Received December 9, 1991; accepted in revised form February 12, 1992. 


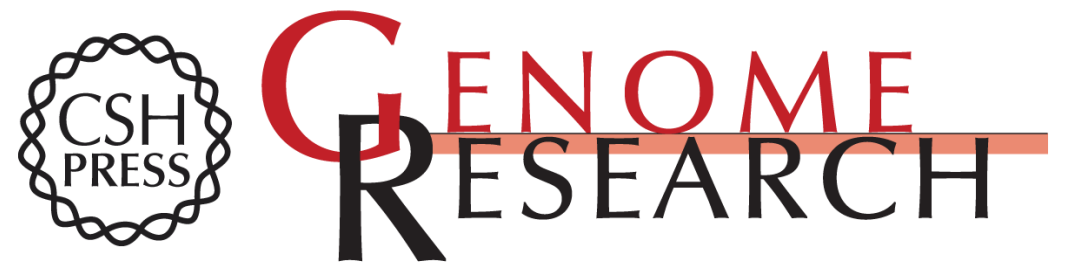

\section{Single-step elimination of contaminating DNA prior to reverse transcriptase PCR.}

D D Dilworth and J R McCarrey

Genome Res. 1992 1: 279-282

Access the most recent version at doi:10.1101/gr.1.4.279

References This article cites 12 articles, 2 of which can be accessed free at:

http://genome.cshlp.org/content/1/4/279.full.html\#ref-list-1

\section{License}

Email Alerting Receive free email alerts when new articles cite this article - sign up in the box at the Service top right corner of the article or click here.

\section{Affordable, Accurate Sequencing.}

To subscribe to Genome Research go to: https://genome.cshlp.org/subscriptions 